Michał Gluzek

Uniwersytet Śląski

\title{
Znaczenie ewaluacji w procesie działań pomocowych na rzecz osób z problemem alkoholowym
}

\author{
The importance of evaluation in the process of aid measures \\ for people with alcoholic problem
}

\begin{abstract}
Abstrakt
Praca z rodziną bądź osobą zmagającą się z problemem alkoholowym stanowi duże wyzwanie dla służb działających w tym obszarze. Nie ulega wątpliwości, że wspieranie osób w tym obszarze jest procesem, który winien być poddany ewaluacji, która może być rozumiana w kategoriach namysłu nad działaniami realizowanymi z konkretną osobą lub rodziną, co przekłada się na budowanie systemów wsparcia odpowiadających na realne potrzeby społeczności lokalnej w obszarze problemu, jakim jest uzależnienie od alkoholu. Rozważania w prezentowanym artykule mają na celu zachęcić praktyków pracy z osobami bądź rodzinami z problemem alkoholowym do podjęcia refleksji w różnych obszarach podejmowanych działań, a przede wszystkim ukazać znaczenie ewaluacji w procesie działań pomocowych na rzecz osób z problemem alkoholowym. Prezentowane w niniejszym artykule treści są wynikiem wieloletniej obserwacji uczestniczącej autora.
\end{abstract}

Słowa kluczowe: rodzina, alkohol, wsparcie, ewaluacja

\section{Wprowadzenie}

Podejmowane na krajowym gruncie działania dotyczące pomocy na rzecz osób bądź całych rodzin zmagających się z problemem alkoholowym pozostają na etapie ciągłego doskonalenia. Silne zróżnicowanie lokalne tychże działań powoduje, że osoby uzależnione bądź współuzależnione w mniejszym bądź większym stopniu mogą skorzystać z pomocy w swoim miejscu zamieszkania. Praktyka realizacji działań pomocowych w ramach systemu pomocy na rzecz tej grupy odbiorców winna być skupiona na tzw. podejściu interdyscyplinarnym, którego podstawową wartością a zarazem założeniem jest ciągła współpraca pomiędzy służbami pracującymi w tymże obszarze - wydaje się, że nikt nie zastanawia się nad tym, jak owa współpraca przebiega nie tylko w sytuacjach skrajnych, kiedy podejmowane są działania wielu służb w chwili zagrożenia zdrowia bądź życia człowieka, kiedy sprawy zostają nagłośnione przez lokalne bądź ogólnopolskie media, ale także w codziennej praktyce pomocowej. 


\section{Działania pomocowe na rzecz osób z problemem alkoholowym jako obszar badań ewaluacyjnych}

Działania pomocowe podejmowane na rzecz osób z problemem alkoholowym jawią się dla wielu praktyków jako obszar wymagający ciągłego procesu ewaluacji, realizowanego w taki sposób, aby na gruncie lokalnym można było zdiagnozować trudności, z jakimi zmagają się specjaliści tworzący lokalny system wsparcia dla osób zmagających się z problemem alkoholowym. W obszarze diagnozowania trudności występujących na gruncie lokalnym wydaje się, że zbyt mało refleksji poświęca się na wiele innych istotnych kwestii: czy specjaliści posiadają wiedzę na temat wzajemnych kompetencji zawodowych; jakie czynniki utrudniają przeprowadzenie sprawnego i skutecznego działania; czy w lokalnym systemie wsparcia znajdują się tzw. czarne plamy, przejawiające się przez brak lokalnych rozwiązań dla określonych przypadków, które pojawiają się w ramach zjawiska uzależnienia od alkoholu; czy w ramach lokalnego działania instytucji na rzecz pomocy nie jest uprawiana spychologia „przerzucania gorącego ziemniaka” - najbardziej skomplikowanych i zawiłych przypadków. Czyż rzetelne prowadzenie badań ewaluacyjnych w tym obszarze nie przyczyni się do zwiększenia współpracy w ramach lokalnego systemu pomocy na rzecz osób z problemem alkoholowym? Nie. Sukces nie leży tylko i wyłącznie w samym przeprowadzeniu badań, ale ich wykorzystaniu, wprowadzeniu rekomendacji w praktykę zawodową. Tworzenie dokumentu tylko i wyłącznie do tzw. szafy nie usprawni lokalnego systemu pomocy. Istotne jest, aby oprócz trudności, które pojawiają się w wymiarze lokalnym, „diagnozować” również to, co jest dobre i przekłada się na jakość pracy z osobą bądź rodziną doświadczającą problemu alkoholowego w celu kontynuacji tychże praktyk (Hryniewicka, 2010, s. 7-16).

System pomocy na rzecz osób bądź rodzin z problemem alkoholowym to także praca wielu podmiotów działających na gruncie lokalnym. Zaliczamy tutaj przede wszystkim: jednostki organizacyjne pomocy społecznej, gminne komisje rozwiązywania problemów alkoholowych, policję, oświatę, ochronę zdrowia, organizacje pozarządowe. Wydaje się, że stanowi to drugi obszar w ramach działań podejmowanych na rzecz osób bądź rodzin zmagających się z problemem alkoholowym stanowiący wyzwanie dla badań ewaluacyjnych. Czy w ramach lokalnych systemów pomocowych dokonuje się analizy jakości świadczonych usług szczególnie na rzecz osób doświadczających problemu alkoholowego? Czy w wymiarze lokalnym posiadamy rzetelne informacje na temat potrzeb szkoleniowych z zakresu pracy z rodzinami z problemem alkoholowym pojawiających się w poszczególnych podmiotach? Czy brak tej informacji nie prowadzi do sytuacji, w której większość specjalistów pozostaje przeszkolona w tym samym obszarze, nie dysponując tym samym kadrą przeszkoloną także w innych kwestiach powiązanych z szeroko rozumianym zjawiskiem uzależnienia od alkoholu? Wreszcie czy osoby pracujące w podmiotach tworzących lokalny system pomocy mają odpowiednie wsparcie psychologiczne, superwizyjne? Czy przypadkiem nie 
planujemy działań na terenie gminy z zakresu profilaktyki, działań projektowych ad hoc, nie zastanawiając się głębiej nad ich sensem oraz trafnością? (Bedyńska, 2012, s. 30-55).

System pomocy na rzecz osób zmagających się z problemem uzależnienia od alkoholu to także osoby, dla których został on powołany, co stanowi najbardziej niepokojącą kwestię z punktu widzenia jego realizacji. Dokonując analizy licznych gminnych strategii, nie sposób dostrzec czasami ani jednego zdania na temat opinii osób z niego korzystających. Dlaczego? Dlaczego mamy do czynienia z sytuacją, w której dokonuje się ewaluacji działań prowadzonych na terenie gminy z zakresu pomocy osobie bądź rodzinie z problemem alkoholowym z wyłączeniem jednego z głównych „źródeł” informacji m.in. z następujących obszarów lokalnego systemu wsparcia:

- kontaktów z placówkami wraz z oceną poszczególnych instytucji;

- ocena pomocy doraźnej oraz całodobowej;

- ocena interwencji policyjnych;

- formy pomocy wraz z oceną ich skuteczności;

- wskazanie form pomocy najbardziej oczekiwanych.

Omawiając kwestię ewaluacji lokalnego systemu wsparcia, nie sposób pominąć także elementów ściśle odnoszących się do samego zjawiska przemocy w rodzinie, który silnie koreluje ze zjawiskiem uzależnienia od alkoholu:

- kontakt z zespołem interdyscyplinarnym oraz grupą roboczą;

- ocena służb realizujących procedurę „Niebieskie Karty”;

- analiza barier i zalet lokalnego systemu przeciwdziałania przemocy.

Przyczyn tej sytuacji możemy szukać w wielu kwestiach, jednak istotne jest zwrócenie uwagi, że bardzo często sprawozdanie z realizacji takowego programu stanowi jedyne źródło informacji na temat lokalnego systemu wsparcia na rzecz osób z problemem alkoholowym, które jest traktowane w kategoriach ewaluacji. Takie sprawozdania niestety ograniczają się do prezentacji suchych faktów o skali zjawiska w danej gminie, ilości posiedzeń grup roboczych, wszczętych oraz zamkniętych procedur „Niebieska Karta”, podjętych działań na rzecz osób doświadczających i stosujących przemoc, co ściśle w wielu przypadkach łączy się z nadużywaniem alkoholu w rodzinach, co stanowi trzeci obszar dla badań ewaluacyjnych, nasuwając tym samym następujące pytania: czy w rzeczywistości lokalnej działania dostosowane są do potrzeb osób uzależnionych i współuzależnionych, a jeśli tak, to skąd posiadamy na ten temat informacje? Czy analizujemy problemy pojawiające się podczas realizacji konkretnych działań m.in. grup wsparcia, programów korekcyjno-edukacyjnych? Czy bierzemy pod uwagę zmienność poruszanych kwestii - czy działania wymagają jakichkolwiek zmian? Jeśli tak, to w jakim zakresie? Co może usprawnić realizację np. działań profilaktycznych realizowanych na terenie gminy? (Bienias, 2012, s. 23-24). Tak zadane pytania w ramach badań ewaluacyjnych stanowią doskonały punkt wyjścia do budowania ewaluacji o jak najbardziej użytecznym charakterze, tym samym przyczyniając się do konstruowania trafnych i możliwych do wprowadzenia rekomendacji, co z kolei stanowi istotę prowadzenia tego typu działań. 


\section{System wsparcia jako interwencja publiczna}

Lokalny system wsparcia to szereg działań, które możemy traktować w kategoriach szeroko rozumianej interwencji publicznej, której celem jest spowodowanie pozytywnej zmiany - w przypadku alkoholu przede wszystkim zmiany społecznej. Działania, które są proponowane w wymiarze lokalnym, winny być ciągiem logicznych punktów, prowadzących w konsekwencji do osiągnięcia ustalonych celów, rozwiązania problemów, które zostały zawarte m.in. w lokalnych diagnozach problemów społecznych. Wówczas możemy mówić dopiero o logice interwencji, sytuacji, w której w sposób najbardziej optymalny angażujemy posiadane zasoby do realizacji działań przeciwdziałających nadużywania alkoholu w rodzinie. Stąd zasadne jest twierdzenie, że ewaluacja odgrywa znaczącą rolę we wdrażaniu interwencji publicznej, stanowiąc swego rodzaju naturalne dopełnienie każdych racjonalnie zaplanowanych działań w ramach lokalnych systemów pomocy na rzecz rodzin oraz osób zmagających się z szeroko rozumianym problemem alkoholowym. Pozwalając tym samym ocenić, czy przyjęte założenia teoretyczne sprawdzają się w rzeczywistości pomocowej.

Często podczas wdrażania nowych rozwiązań, które mają wzmocnić lokalny system pomocy dla osób bądź rodzin z problemem alkoholowym, zapomina się o kluczowych punktach, które powinny zostać uwzględnione na poszczególnych etapach przedsięwzięcia:

- przed wdrożeniem nowych rozwiązań: ocena trafności planowanej interwencji, jej logiki oraz planowanego sposobu realizacji.

- w trakcie realizacji nowych rozwiązań: identyfikacja czynników, które z punktu widzenia osiągnięcia zamierzonych celów mogą utrudnić ich realizację, ocena czynników sprzyjających osiągnięciu realizacji np. określonego działania z zakresu przeciwdziałania przemocy w rodzinie.

- po zakończeniu realizacji nowych rozwiązań: podsumowanie efektów działań, utworzenie rekomendacji dla przyszłych przedsięwzięć w ramach systemu pomocowego (Olejniczak, 2012, s. 25-57).

\section{Podsumowanie}

System pomocy rodzinie bądź osobie zmagającej się z problemem alkoholowym, jak już wcześniej wspomniano, to szereg podejmowanych działań, które jednak nie powinny ograniczać wolności osób, które w ramach tego systemu są wspomagane. Działania pomocowe z zakresu przeciwdziałania temu negatywnemu zjawisku w rodzinie powinny uwzględniać ich ocenę nie tylko pod względem ich zakresu, ale czy sami zainteresowani (osoby uzależnione bądź współuzależnione) uczestniczyli w projektowaniu owych działań oraz, co najważniejsze, w ich realizowaniu - osoba bądź rodzina korzystająca z systemu wsparcia jest traktowana w sposób podmiotowy czy przedmiotowy? Oczywiste jest, że działania pomocowe podejmowane na rzecz osób bądź rodzin zmagających się z problemem 
alkoholowym można ewaluować pod wieloma innymi względami, chociaż wymiar skuteczności, trafności oraz użyteczności w przypadku tej grupy odbiorców działań wydaje się najbardziej istotny. Ważnym aspektem przy omawianiu systemu na rzecz tychże rodzin jako obszaru badań ewaluacyjnych jest zwrócenie uwagi, że każde z podejść w tym obszarze może stwarzać stosunkowo duże problemy (Trawkowska, 2009, s. 129-145). W przypadku chociażby zbadania skuteczności działań w ramach działań pomocowych w rodzinie bardzo wiele zależy od tego, jak zostały sformułowane podstawowe cele, ile ich jest, w jakiej wzajemnej relacji pozostają względem siebie. Z kolei możliwość oceny użyteczności podejmowanych działań ściśle wiąże się z konceptualizacją i operacjonalizacją dobra klientów. Ponadto wymaga porównania celów i skutków prowadzonej interwencji z potrzebami osób uzależnionych bądź współuzależnionych, co z kolei wymaga szczegółowego, obiektywnego oraz rzetelnego opisu. Na poziomie budowania lokalnych systemów wsparcia na rzecz osób bądź rodzin zmagających się z problemem alkoholowym często odwołuje się do pojęć „potrzeba” oraz „zaspokajanie”. Jeśli zatem lokalny system wsparcia przyjmuje za główny cel zaspokajanie potrzeb osób uzależnionych bądź współuzależnionych, istotne jest posiadanie rzetelnych oraz całościowych informacji na temat tych potrzeb, uwzględniając m.in. zróżnicowanie wiekowe, płciowe oraz materialne osób korzystających ze wsparcia w ramach tego systemu. W kumulowaniu i rozważaniu tych informacji należy zwrócić szczególną uwagę na odróżnienie potrzeb od pragnień osób wspomaganych. Badania ewaluacyjne mogą w znacznym stopniu przyczynić się do znalezienia rozwiązań w tych obszarach, szczególnie z uwagi na fakt, że szeroko rozumiana pomoc społeczna to ciągłe poszukiwanie adekwatnych rozwiązań (Ciczkowska, 2017, s. 83-93).

\section{Bibliografia}

Bedyńska S. (2013), Ewaluacja lokalnego systemu przeciwdziałania przemocy, SWPS, Warszawa.

Bienias S. (2012), Ewaluacja. Poradnik dla pracowników administracji publicznej, Ministerstwo Rozwoju Regionalnego, Warszawa.

Ciczkowska M. (2017), (Nie)odkryte możliwości wspierania rodziny w środowisku lokalnym, Wydawnictwo UWM, Olsztyn.

Hryniewicka A. (2010), Podstawy ewaluacji dla pomocy społecznej, ROPS, Kraków.

Olejniczak K. (2012), Organizacje uczące się, SCHOLAR, Warszawa.

Trawkowska D. (2009), Działania pozorne w pomocy społecznej, Wydawnictwo Uniwersytetu Śląskiego, Katowice.

\footnotetext{
Abstract

Working with a family or a person struggling with an alcohol problem is a great challenge for services operating in this area. There is no doubt that providing such support is a process that should be subject to evaluation, which can be understood in terms of reflecting on activities that are carried out with a specific person or family, which translates into building support systems responding to the real needs of local communities regarding alcohol dependency. The considerations in the presented article are intended to encourage practitioners working with people or families with alcohol issues to deliberate on various areas of undertaken activities.
}

Keywords: family, alcohol, support, evaluation 